American Journal of Anatomy and Physiology
(ISSN:2637-4714)

\title{
THE BENEFITS OF FOLLOW-UP BY THE MULTIDISCIPLINARY TEAM IN HEALTH FOR PEOPLE WITH SYSTEMIC LUPUS ERYTHEMATOSUS
}

\section{Ziane da Conceição das Mercês}

Pós Graduanda pela Faculdade Estácio de Sá. Nutricionista Responsável Técnica na Secretaria de Educação no Município de Aveiro-PA

\section{ABSTRACT}

Objective: Discuss the benefits of monitoring by a multidisciplinary health team for the treatment of patients with systemic lupus erythematosus. Methods: The research proposal is based on a review of bibliographic references, with a source of synthesizing results obtained through secondary research on the theme, in a methodical and orderly manner, seeking to contribute to the knowledge on the proposed subject. Results: Through a thorough analysis of theoretical references, 30 scientific articles were selected that alluded to the systemic lupus erythematosus pathology. Systemic lupus is characterized by articular, cutaneous, renal, vascular, serous, nervous manifestations, decreased mobility, muscle strength, physical conditioning and quality of sleep, increased joint stiffness, pain and fatigue and can cause, even depression, obesity and / or malnutrition, impacting quality of life. Conclusion: The research presented relevant results on the monitoring by the multidisciplinary health team for the treatment of patients diagnosed with systemic lupus erythematosus, presenting data that justify the construction of a structured support network, which will contribute to the therapy of this patient, providing well-being and improvements in quality of life. Taking into account the situation that the pathology presents, these data are at least disturbing. These bases made it possible to expand the discernment on the subject, opening a succession of discussions to find proposals and resolutions that can corroborate with the treatment of people diagnosed with chronic diseases such as SLE.

Keywords: Chronic disease, multidisciplinary monitoring, treatment.
*Correspondence to Author:

Ziane da Conceição das Mercês

Pós Graduanda pela Faculdade Estácio de Sá. Nutricionista Responsável Técnica na Secretaria de Educação no Município de Aveiro$P A$

How to cite this article:

Ziane da Conceição das Mercês. THE BENEFITS OF FOLLOW-UP BY THE MULTIDISCIPLINARY TEAM IN HEALTH FOR PEOPLE WITH SYSTEMIC LUPUS ERYTHEMATOSUS. American Journal of Anatomy and Physiology, 2021, $4: 17$.

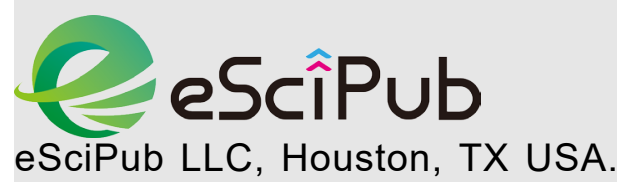
eSciPub LLC, Houston, TX USA. Website: https://escipub.com/ 


\section{INTRODUCTION}

Systemic lupus erythematosus (SLE) is a chronic autoimmune inflammatory disease, based on an overproduction of autoantibodies by $B$ lymphocytes and the failure of suppressor and immunoregulation mechanisms. These autoantibodies, in turn, bind to the cells and activate the complement system, triggering an inflammation that will promote characteristics in the cells and adjacent tissues ${ }^{1}$.

The physiological function of the immune system is to defend the organism against any unknown element, such as infectious microorganisms. However, there may be a lapse in this system, causing an attack against the organism itself, due to a failure related to immunological selftolerance ${ }^{2}$.

SLE is an autoimmune disease with a predominantly inflammatory pattern, which can affect several systems, the tegumentary and articular being the most common. The intensity of progression is variable (weeks to months) and its appearance is more prevalent in women of childbearing age $^{3}$.

The etiology is not clearly defined, but it is known that there are several factors involved (genetic, viral, hormonal and environmental) associated with an imbalance in the functioning of the immune system. SLE patients have a higher concentration of nuclear antibodies, mainly antiDNA, anti-Sm, anti-RNP, anti-SSA (Ro) and antiSSB (La) ${ }^{4}$.

The prevalence of SLE cases is higher in women than men, at a 10: 1 ratio and the mortality rate reaches $90.7 \%$ in females ${ }^{5}$.

The most common signs and symptoms of SLE are fatigue, fever, weight loss, loss of appetite, photosensitivity, skin and joint injuries. There may also be involvement of other organs such as the kidney, the heart or the central nervous system (brain) ${ }^{2}$.

Due to the clinical polymorphism, it becomes more difficult to recognize and differentiate the patient's condition, causing a late diagnosis, until then, lack of adequate therapy, leading, therefore, to a greater evolution of the disease in the patient ${ }^{2}$.

The multiple and recurrent symptoms presented by SLE have an influence on the patient's life in different ways, whether due to impairment of function in different systems and self-image, or even to the restriction of social participation. All of these situations, however, directly affect the quality of life of individuals affected by the disease $^{6}$.

According to the literature, mortality in SLE follows a bimodal pattern: in the early stages, death is caused mainly by infection, followed by severe renal or central nervous system (CNS) activity; in the more advanced stages of the disease, there is an increase in mortality from cardiovascular diseases associated with atherosclerosis, partially related to corticosteroid therapy and chronic inflammation ${ }^{5}$.

Although the survival of lupus patients has increased considerably in the last 50 years, thanks to the development of new drugs that reduce outbreaks of the disease, their quality of life remains low, as the individual is harmed in different domains, when compared to the population in general, due to signs and symptoms such as depression, fatigue, fibromyalgia, cognitive and nutritional changes ${ }^{7}$.

As it is a difficult to control disease, its treatment aims to prevent acute outbreaks of vasculitis, as well as to avoid permanent damage to the affected organs, arresting their progression and / or maintaining their remission ${ }^{8}$.

According to the content described on the pathology Systemic Lupus Erythematosus, the referred research asks: Do patients undergoing continuous treatment for remission of the disease receive follow-up with other health professionals, and what benefits will this followup bring to the treatment of patients with SLE?

In this sense, the study is justified by the search to demonstrate the benefits of monitoring by a multidisciplinary health team for the treatment of those affected by SLE pathology, which may contribute to the prognosis, improving the 
patient's clinical, physical, psychological and nutritional status.

According to what was exposed about SLE, the purpose of this study was to discuss the benefits of monitoring by a multidisciplinary health team for the treatment of patients with systemic lupus erythematosus.

\section{METHODS}

The research proposal is based on a review of bibliographic references, in order to synthesize results obtained through secondary research on the theme, in a methodical and orderly manner, seeking to contribute to the knowledge on the proposed subject. The data used were based on scientific articles taken from reliable sources such as: The Scientific Electronic Library Online (Scielo), Bireme, Latin American and Caribbean Literature in Health Sciences (Lilacs), Virtual Health Library, using the keywords: Lupus systemic erythematosus; Systemic lupus; LES, using the content published in the last five years (2015-2020).

\section{RESULTS}

The research was carried out in a literary review format and the data related to the search are illustrated in figure -1 .

Figure 1. Flowchart of the article selection process for the production of the scientific study.

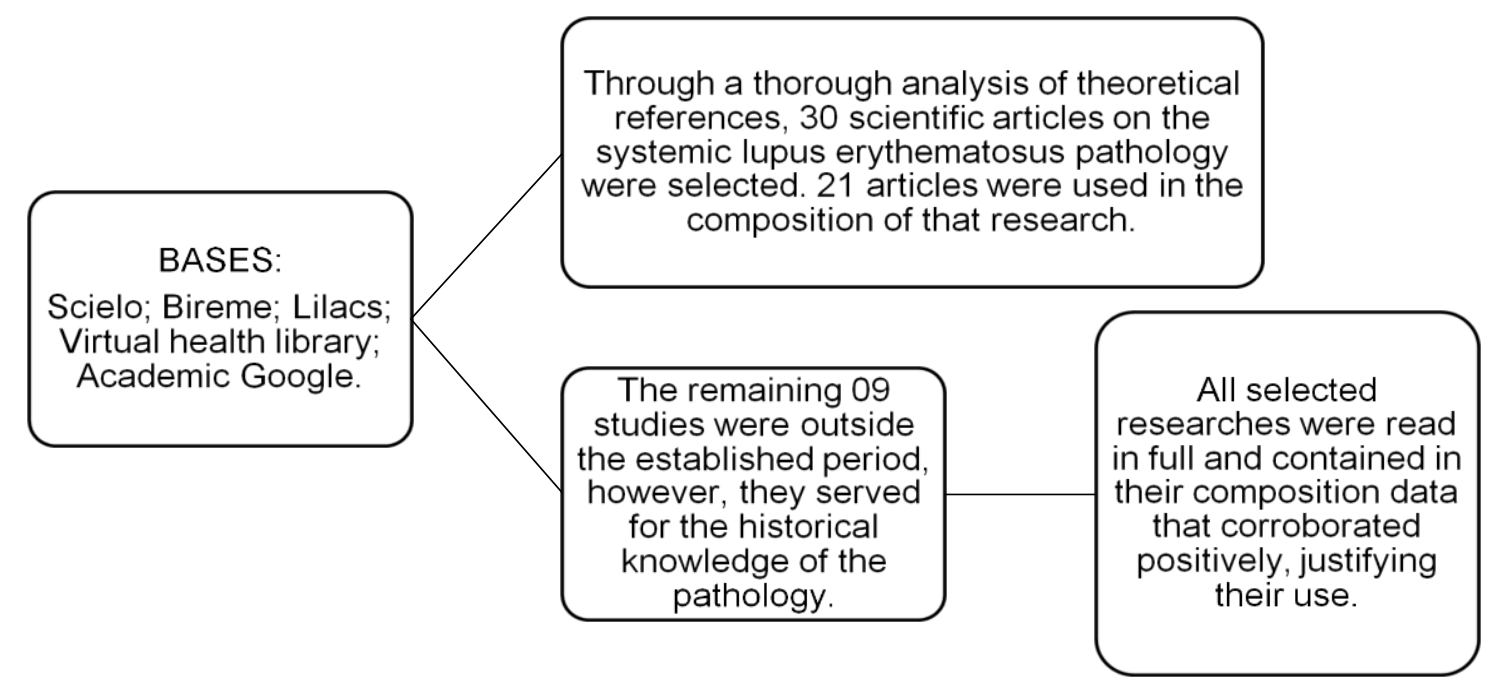

Source: Research data.

SLE is characterized by articular, cutaneous, renal, vascular, serous, nervous manifestations, decreased mobility, muscle strength, physical conditioning and quality of sleep, increased joint stiffness, pain and fatigue and can cause, even depression, obesity and / or malnutrition, impacting quality of life' .

They went on to analyze scientific studies in a systematic way, which referenced relevant data on the systemic lupus pathology. (Table-1)

\section{DISCUSSION}

The treatment of SLE depends on the manifestations presented by the patient, it may be necessary to introduce several or no drugs in the active phase or for remission of the disease. The patient with SLE needs support in addition to drug treatment: guidance on the disease, physical activity, psychosocial and diet therapy support. These are essential measures for the well-being of patients with SLE ${ }^{13}$.

In general, due to the variety of biopsychic consequences that systemic lupus erythematosus can cause, it is necessary for patients to know about the disease and its implications, to know how to differentiate the symptoms caused by other health conditions, to understand the importance of medical and psychological monitoring, in which, they will make all the difference to the treatment, as well as, receive guidance to avoid the sun and the lamps due to UV radiation, perform physical activities according to their limitations, adopt a balanced diet, avoid smoking and suspend the use contraceptives ${ }^{14}$. 
Table 1. Characterization of the selected data according to authorship, journal, year, theme, population studied and main results on studies related to lupus with different health professionals, published between the years 2015-2020.

\begin{tabular}{|c|c|c|c|}
\hline $\begin{array}{l}\text { Author's name. } \\
\text { Periodic, Year }\end{array}$ & Publication Title & Study population & Results \\
\hline $\begin{array}{l}\text { Jorge et al. }{ }^{9} \\
\text { Rev. Ciênc. Méd. } \\
\text { Biol } \\
2016\end{array}$ & $\begin{array}{l}\text { Physiotherapeutic } \\
\text { intervention in an } \\
\text { individual with } \\
\text { rheumatoid arthritis, } \\
\text { systemic lupus } \\
\text { erythematosus and } \\
\text { Sjogren's syndrome: a } \\
\text { case report }\end{array}$ & $\begin{array}{l}\text { A 56-year-old female } \\
\text { individual participated in the } \\
\text { study, who had a medical } \\
\text { diagnosis of Rheumatoid } \\
\text { Arthritis and SLE for } 16 \\
\text { years. }\end{array}$ & $\begin{array}{l}\text { Physical therapy seeks to assess pain, } \\
\text { fight inflammatory processes, preserve } \\
\text { range of motion and muscle activity, } \\
\text { prevent deformities, restore } \\
\text { cardiopulmonary status, promote physical, } \\
\text { psychological and social well-being, as } \\
\text { well as improve cardiorespiratory status, } \\
\text { balance, gait, proprioception and the } \\
\text { quality of life of individuals. }\end{array}$ \\
\hline
\end{tabular}

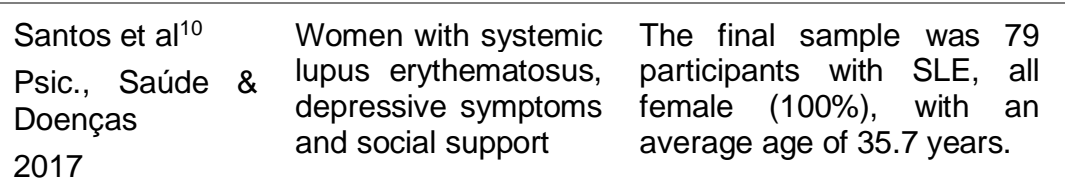

The present study showed a high prevalence of depressive symptoms in patients with SLE. This result reinforces the importance of building public policies in Brazil that guarantee, especially, the correct diagnosis, access to adequate and complete treatment with the provision of medication, exams and consultations by SUS, as well as prevention, protection and quality of care. life.

\begin{tabular}{|c|c|c|c|c|}
\hline \multicolumn{2}{|c|}{ Saldanha et al. ${ }^{11}$} & Systemic & lupus & The female LMRE patient, 20 \\
\hline & Health & erythematosus & & years old, leucoderma, with \\
\hline Invest. & & Dentistry: a & case & SLE for approximately 8 \\
\hline 2015 & & & & $\begin{array}{l}\text { treatment, was admitted to } \\
\text { the Hospital Universitário } \\
\text { Maria Aparecida Pedrossian }\end{array}$ \\
\hline & & & & $\begin{array}{l}\text { NHU / UFMS due to } \\
\text { complications of the disease. }\end{array}$ \\
\hline
\end{tabular}

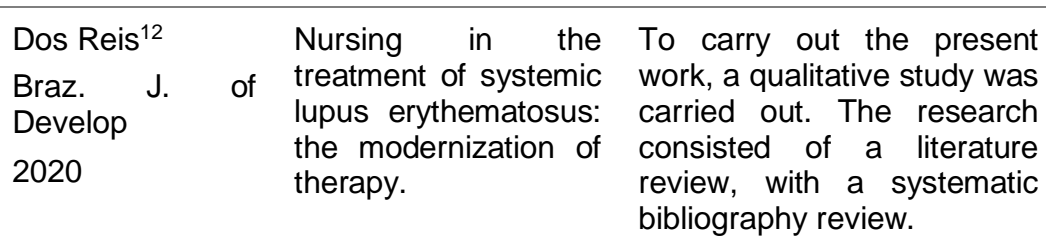

The patient received guidance on the importance of maintaining good oral hygiene $(\mathrm{OH})$ while hospitalized and as a daily routine, regarding the possibility of ulcerated lesions on the tongue as a result of SLE and pain and discomfort being related not only to ulcers, but the presence of oral candidiasis due to high doses of corticosteroids for the treatment of SLE.

In SLE patients, nursing actions should promote strategies to reduce the damage resulting from the disease and reduce treatment-induced morbidity. Although the treatment must be done individually for each patient, according to the severity of the disease and the needs of each organism, there are several aspects involved

\begin{tabular}{|c|c|c|c|}
\hline \multicolumn{2}{|c|}{ Almeida et $\mathrm{al}^{13}$. } & Anthropometric profile & Forty SLE patients were \\
\hline $\begin{array}{l}\text { Arq. } \\
\text { Med. }\end{array}$ & Catarin. & $\begin{array}{l}\text { and food consumption } \\
\text { of women with }\end{array}$ & $\begin{array}{l}\text { studied, with a mean age of } \\
34 \text { years. }\end{array}$ \\
\hline 2017 & & $\begin{array}{l}\text { systemıc } \\
\text { erythematosus }\end{array}$ & \\
\hline
\end{tabular}

The results of the study were characterized, according to the BMI, that $40 \%$ of the sample had eutrophic, $32.5 \%$ were overweight and $27.5 \%$ were obese, resulting in $60 \%$ being overweight. The accumulation of fat can lead to the development of the metabolic syndrome, in addition to increasing proinflammatory cytokines.

Source: Research data.

One of the main problems that the public health system faces is the patient's abandonment of treatment or incorrect compliance with the guidelines prescribed by health professionals. Non-adherence to treatments is probably the most important cause of failure of therapies, AJAP:https://escipub.com/american-journal-of-anatomy-and-physiology/ introducing dysfunctions in the health system through increased morbidity and mortality ${ }^{17}$.

According to Klumb's description ${ }^{15}$, most lupus patients have normal lives, however when compared to the general population, overall 
survival is lower. Cancer, disease activity, infection and diseases secondary to lupus such as kidney damage and cardiovascular disease are the main causes of death. Drug treatment is crucial, but other tools can be used to support lupus, such as the dietary approach, the integration of this carrier in society and physical activity.

According to Feitosa et al. ${ }^{16}$ several studies highlight that until the definitive diagnosis of the disease, many patients are treated by several medical specialties. As a result, the frequency of consultations and symptoms cause insecurity, fear, anguish and stress to the patient. With the diagnosis of the disease already defined, along with the feelings, other emotional states will be added, resulting from the treatment now, which will increase their uncertainties.

According to Neder ${ }^{17}$ constitutional symptoms such as fever, anorexia, weight loss, fatigue and adynamia are among the main initial clinical manifestations of the disease and, during the socalled periods of activity, such symptoms and signs may be present between $40 \%$ and $90 \%$ of the patients. Other manifestations that deserve to be highlighted in SLE patients are musculoskeletal, almost always those responsible for patients to see the specialist, especially arthritis and or arthralgia, which, in addition to being frequent, tend to be the most common initial manifestations. Its incidence can be observed between $50 \%$ and $95 \%$ of patients during the evolutionary process of the disease.

Mantins ${ }^{18}$ describes the dietary guidelines for SLE patients, being essential to contribute to the control of the inflammatory condition of the disease and the complications of the treatment of SLE itself. Cardiovascular risk seems to be increased in lupus patients, since it is common to find conditions associated with atherosclerosis, such as dyslipidemia, diabetes mellitus (DM), metabolic syndrome (MS) and obesity. Thus, diet therapy is a crucial tool to be used in order to alleviate these complications. Obesity and malnutrition can negatively influence the response to SLE treatment, since it triggers systemic inflammation and that causes immunosuppression.

Da Silva ${ }^{19}$ presents the nursing process as a systematic method of providing care that aims to achieve desired results. Based on these principles, SLE and its complications present an interesting framework for nursing interventions aimed at reducing clinical outcomes of decompensation and improving the quality of life of affected patients.

According to Costa et al. ${ }^{20}$, regarding oral manifestations of systemic diseases of autoimmune / dermatological origin, including SLE, the data are not very clear in terms of incidence, however, in this study, approximately $60 \%$ of lesions were found in the oral mucosa. Occurrence considered significant, which alerts us to the importance of including oral structures in the physical examination of patients with immunodermatological disorders ${ }^{11}$.

In Brazil, studies that call attention to depressive disorders in SLE patients are rare. Investigating this relationship can contribute to more effective therapeutic interventions. In addition, studies leave doubts as to whether depressive states could contribute to non-adherence to treatment ${ }^{17}$.

According to data reported by the research by Neder $^{17}$, the patients who participated in their study did not have multiprofessional assistance in their care. Some showed depressive behaviors that can be related to the abandonment of treatment and to worsening of the disease.

Para a Organização Mundial de Saúde $(\mathrm{OMS})^{21}$, adesão ao tratamento corresponde ao grau de concordância entre as recomendações do prestador de cuidados de saúde e o comportamento do paciente relativamente ao regime terapêutico proposto em comum acordo.

\section{CONCLUSION}

The research presented relevant results on the monitoring by the multidisciplinary health team for the treatment of patients diagnosed with systemic lupus erythematosus, presenting data 
that justify the construction of a structured support network, which will contribute to the therapy of this patient, providing well-being and improvements in quality of life. Taking into account the situation that the pathology presents, these data are at least disturbing. These bases made it possible to expand the discernment on the subject, opening a succession of discussions to find proposals and resolutions that can corroborate the treatment of people diagnosed with chronic diseases such as SLE.

\section{REFERENCES}

[1]. Sousa ALM, Souza ECSS, Soares GAFS, Schmitt LM, Maia LLF, Bessa NB, Bernardes CTV. General aspects of systemic lupus erythematosus in pregnancy. RESU - Health Education Magazine: v7, suplemento 1,2019.

[2]. Prado DM, Amaral BA, Duarte SFP, Vale AE, Silva ML, Rocha AR, Sousa VM. Profile of Patients with Systemic Lupus Erythematosus treated by the Specialized Component of Pharmaceutical Assistance in a Health Region. Rev. Mult. Psic. V.11, N. 38. 2017.

[3]. Pereira Júnior CJ, Santos LPC, Silva PAM, Fernandes FA. Approach and management of systemic lupus erythematosus in pregnancy. eScientia, Belo Horizonte, v. 12, n. 2, p. 1-5, 2019.

[4]. Shaikh MF, Jordan N, et al. Systemics lúpus erythematosus. Clin Med (Lond). 17(1): 2017.

[5]. Costi LR, Iwamoto HM, Neves DCO, Caldas CAM. Mortality from systemic lupus erythematosus in Brazil: assessment of causes according to the government's health database. Brazilian Journal of Rheumatology, v. 57, n. 6 , p. 574-582, 2017.

[6]. Corrêa RD, Oliveira LP, Santana Junior WB, Telles RW, Fereira GA, Lanna CCD. "What you always wanted to know about lupus and never had the courage to ask ": proposed patient education program. Rev Med Minas Gerais. 25(3), 2015.387-392.

[7]. Furlan FLS, Lemes MA, Pires CTF, Azevedo G, Bernardi GF, Simões YS, et al. Quality of life in treatment of systemic lupus erythematosus with antimalarials. Rev Soc Bras Clin Med. 16(2): 26, 2018.

[8]. Skare TL, Dagostini JS, Zanardi PI, Nisihara RM. Infections and systemic lupus erythematosus. Einstein.14(1):47-51, 2016.

[9]. Jorge MSG, Comin JDP, Wibelinger LM. Physiotherapeutic intervention in an individual with rheumatoid arthritis, systemic lupus erythematosus and Sjogren's syndrome: a case report. Rev. Ciênc. Méd. Biol., Salvador, v. 15, n. 2, p. 231-237, mai./ago. 2016.

[10]. Santos, LMO, Vilar MJ, Maia EMC. Women with systemic lupus erythematosus, depressive symptoms and social support. Psych., Health \& Diseases vol.18 no.1 Lisboa abr. 2017.

[11]. Saldanha KFD, Costa DC, Da Silva JCL, Gaetti Jardim EC. Systemic lupus erythematosus in Dentistry: a case report. Arch Health Invest. 4(6): 21-24,2015.

[12]. Dos Reis TS. Nursing in the treatment of systemic lupus erythematosus: the modernization of therapy. Braz. J. of Develop., Curitiba, v. 6, n. 6, p. 6710-6726 jun. 2020.

[13]. Almeida CS, Mendes ALRF, Cavalcante ACM, Arruda SPM, Silva FR. Anthropometric profile and food consumption of women with systemic lupus erythematosus. Arq. Catarin. Med. 46(4):103-117. Out/dez 2017.

[14]. Guerreiro MGU, Sousa MNA. Quality of life and psychological distress in women with systemic lupus erythematosus. Health and Development Magazine.13(16):72-85. 2019.

[15]. Klumb EM, Silva CAA, Lanna CCD, Sato El, Borba EF, Brenol JCT et al. Consensus of the Brazilian Society of Rheumatology for the diagnosis, management and treatment of lupus nephritis. Rev Bras Reumatol, v. 55, n.1, p.1-21. 2015.

[16]. Feitosa MB, Da Silva CRL, Silva MLA, Araújo CSB, De Moura MERB, Alencar APA, Silva ÉMG. Systemic lupus erythematosus: a clinical assistance analysis / Systemic erythematous lupus: a clinical assistance analysis. Brazilian Journal of Development,6(6), 2020. 3445134463.

[17]. Neder PRB. Systemic lupus erythematosus: comparative study between intervention models for treatment adherence, 2015.

[18]. Martins SF. Nutritional status, biochemistry and food consumption in systemic lupus erythematosus (SLE): a literature review. João Pessoa, 2016.

[19]. Da Silva TPC, Dos Santos SCD, Gallasch CH, Silva AP, Gomes HF, Pérez Júnior EF. Main nursing care for patients with Systemic Lupus Erythematosus: experience report. ProUniverSUS Magazine, 10(2), 2019. 39-47.

[20]. Costa JL, Soares MSM, Komatsu AA, Albuquerque ACL. Patients with systemic diseases of autoimmune / dermatological origin. Incidence of oral manifestations and literature review. Rev Bras Health Sciences. 2009;13(3):49-54. 
Ziane da Conceição das Mercês, AJAP, 2021, 4:17

[21]. World Health Organization -WHO (2003).

Burden of Mental and Behavioural Disorders,

$2003 . \quad$ Disponível em:

http://www.who.int/whr/2001/chapter2/en/index

4.html. Acessado em: 21/09/ 2020. 